\title{
DOES USING SOCIAL NETWORKING EXPOSE STUDENTS TO EXCESSIVE RISK?
}

\author{
Hal Records, Bryant University, hrecords@bryant.edu \\ Suhong Li, Bryant University, sli@bryant.edu \\ Robert Behling, Arrowrock Technology, behlingr@gmail.com
}

\begin{abstract}
Many of today's students spend a great deal of time online, and social networking is an important part of their daily communications. This study investigates student perception of risks associated with the use of social media and is based on a survey of 225 students from a northeast university. Findings indicate that students are aware of risks, but tend to believe that the benefits of use outweigh the risks.
\end{abstract}

Keywords: Social Networking, Social Media, Risks of Social Networking, Social Networking Security

\section{INTRODUCTION}

There is little question that social networking sites are exploding, both in numbers of sites and numbers of users. Tens of thousands of new users are signing up every day. It has been reported that Facebook alone has more than $750,000,000$ and perhaps as many as 800,000,000 users, with two thirds of them from outside the United States (Wharton, 2011, Sharma, 2012). Users visit their favorite web sites to keep up with news, entertainment, and to enhance their individual social life through sharing personal information with others. It is expected that people will conduct more and more of their online lives through social media (Wharton, 2008). As an educational tool social media enriches the learning experience by allowing students to connect and interact in new and exciting ways (Lederer, 2012)

\section{BACKGROUND}

Social Networking Risks. Along with the perceived value of social networking there are a number of risks as well. Some believe that social networks are very risky because they are inherently unstable (Wharton, 2008). Creating a profile exposes individuals to possible identity theft, and downloading files (83\% of users do) may bring with them viruses that can attack and corrupt the user's computer or secretly collect personal information. Many people are unaware of the risks when they create a profile and do not realize that millions of people can look at the profile they post (Hardy 2012). For example, flagging another users profile for pornographic or inappropriate images may provide a scammer with access to the full user profile (Letzing, 2011).

Scammers are taking advantage of weak hacker protection at both Facebook and Twitter (Fowler, 2012) to harm individuals. If you are logged in to Skype a thief can effectively track where you are, and in some instances what you download (Sengupta(2), 2011). Users can download programs to customize their Facebook page, but in doing so they may open their computer to have unwanted large and splashy ads appear on their screen (Steel. 2011). Also, for some social networking sites have become addictive, requiring students to often choose between doing schoolwork and being on the net.

As online networks grow, the collection of personal and other information expands, and advertisers and others find new ways to access and use this information, often without the individual's knowledge. To make the issue more confusing, sites often change their privacy rules and policies, usually not to the benefit to the user (Wharton, 2010). This is illustrated by a recent announcement by Google that they will eliminate more than 60 different privacy policies and consolidate all services under a single set of guidelines for products such as You Tube, Gmail and Google search, effectively allowing the company to utilize data collected in one user area to be integrated across all 


\section{Issues in Information Systems}

Volume 13, Issue 2, 380-389, 2012

platforms. This may lead to data being used out of context and without user knowledge or approval (Wharton, 2012). In addition, with the product Timeline, Facebook has taken control over user data and has made this information accessible to others without the consent of the user (Technolog, 2012). Google will track activity across all of its sites, however personal data will not be combined with browsing data, as they have signed a 20 year privacy agreement with the FTC (Angwin, 2012). The FTC agreement came about because Google was found guilty of allowing and profiting from ads on their website to sell illegal pharmaceutical drugs. They also have pending lawsuits by record companies charging they profit from illegal internet music piracy (Catan, 2012).

Social Media Partnering Risks. In addition to privacy policy concerns, there are social media partnering issues. Facebook has an average of 10,000 external websites (more than 2.5 million since 2007) integrate with their platforms each day, allowing users to take Facebook "Friends" to other websites where privacy policies may or may not protect the user (Wharton, 2011).

Facebook continues to define privacy through new features and it's ever changing policies using an "Act now, apologize later" approach. Because Facebook profits from the sale of user data, they utilize often confusing "opt out" privacy settings. It is important to recognize that the goal of Facebook is to create more opportunities for targeted advertising, and they have to balance user demands with those of advertisers and the law. Many users do not comprehend what they give up when they join Facebook (Wharton, 2010). Recently the government has accused Facebook of engaging in unfair and deceptive practices, including sharing information with outside application developers, contrary to representations made to users (Sergupta(1), 2011). In India, Facebook is fighting against increasing censorship demands from the government, arguing that they are not legally responsible for monitoring their web site and removing objectionable materials (Sharma, 2012). A recent Harris Poll found that people polled do not believe Facebook is sincere in its communications, maintains high ethical standards, or will do the right thing if faced with a problem (Harris Poll, 2012).

Assessing Social Media Risks. Assessing and addressing social networking risks remains the responsibility of the user. Starting with their user profile, users need to keep in mind that creating an unflattering profile (talk and pictures of drinking, drugs, etc) will impact their future. CareerBuilder reported that survey results show $45 \%$ of employers use social networking sites to research job candidates. (CareerBuilder, 2009). Trusting websites to protect private information is risky, and potential employers, marketing organizations and identity thieves all have shown the ability to access "private" information. Also, the online world creates the opportunity to develop relationships with strangers without ever meeting them, a potentially risky activity (Hardy, 2012). There is no doubt that social networking platforms will provide a very dynamic and at times confusing environment (Wharton, 2008). There are many benefits, including enhancing student engagement, improving communication among students and teachers, and help in finding employment. The downside includes the risk that social media will become a distraction, cyber bulling and harassing students online, and discouraging face to face communication (Lederer, 2012). The key for individuals to successfully use social media is to control risk when using social networking applications and to exercise care when deciding what personal information to put on the site. Listed below is a brief summary of some of the more important dangers of using Social Networking for college students.

1. Password sloth - using the same password for all social media sites gives scammers and hackers easy access once a password is found.

2. Students or others posting inappropriate content, inaccurate, irrelevant or false information.

3. Not understanding privacy policies and issues such as "opt out" rather than "opt in."

4. Making "friends" with the wrong people.

5. Scams to divulge sensitive information or click a link leading to an infected site.

6. Inappropriate search by employers, identity thieves, marketing organizations and others.

7. Students seeking jobs are hurt because of posting:

a. Inappropriate photos

b. Content about inappropriate activities such as drinking or drugs 


\section{Issues in Information Systems \\ Volume 13, Issue 2, 380-389, 2012}

c. Inappropriate comments about school, professors, others

d. Discriminatory comments

e. Sharing confidential information inappropriately

8. Think of Facebook as a reference, when checked you want to look good

\section{RESEARCH METHODOLOGY}

\section{Survey Design and Administration}

This study is based on survey data obtained from students and faculty at a Northeast University in April of 2012. Surveys were made available to students in electronic format. Electronic responses were collected via SurveyMonkey. A total of 225 usable surveys were collected from students who were primarily sophomores and freshmen. Respondent demographics are male 59.9\% and female $40.1 \%$. Survey questions were selected by creating a list of social media products and electronic devices commonly used by students.

\section{Research Questions}

Research questions are: What social networking programs are used? What electronic devices are used? How much time is spent using social networking? With whom do students communicate using social networking? How many people see your social network postings? Does social networking negatively impact getting schoolwork completed on time and to the best of your ability? How satisfied are you with social media sites' delivery of security and privacy policies and features? Who has access to and uses your social media postings? What are the primary benefits and risks of using social networking? Do the benefits outweigh risks? Are there gender differences in these perceptions?

\section{FINDINGS}

The primary social media programs used are Facebook (95.5\%), Twitter (62.9\%), Linked-In (30.3\%), Google+ (15.8\%), and MySpace (.5\%). Clearly Facebook is dominant, with Twitter running a respectable second. Indications are that Linked-In may receive higher utilization from upper class students who are more engaged in searches for internships and jobs. Also, given that Google+ is a relative newcomer to the social media scene and that Google has such significant presence in search engines, e-mail and video, it is likely that the use of Google+ will increase. It appears that for whatever reasons MySpace is no longer relevant.

Electronic devices used by students for social networking include: Laptop Computers (92\%), I-Devices including I-Phones and I-Pads (55.4\%), Android Devices (24.6\%), and Notepads (5.8\%). Use of Laptop Computers may be disproportionately high in our sample because laptops are provided by the University to all students. It is clear based on use of "I" and Android devices that smartphones are becoming mainstream social networking devices.

Time spent on Social Media is a significant factor in academic performance. Of the students surveyed $95.9 \%$ use social media for one or more hours every day. The breakdown is $40.3 \%$ for $1-2$ hours per day, $27.1 \%$ for $2-3$ hours, $15.8 \%$ for $3-4$ hours, $12.7 \%$ for greater than 4 hours per day and only $4.1 \%$ do not do social networking. Social networking time is spent communicating with friends $(96.8 \%)$, classmates $(86.3 \%)$, family $(75.7 \%)$, businesses $(29.7 \%)$ and others $(9.5 \%)$. Students were asked about the impact of time spent using social networking on getting their assignments and other schoolwork completed on time and to the best of their ability. In order to better understand their perceptions, responses were aggregated into two groups, those who use social media less than or equal to two hours per day (44.4\%) that we call moderate users and those who use it more than two hours per day $(55.6 \%)$ that we call heavy users. As shown by Table $1,50 \%$ of moderate users and nearly $65 \%$ of heavy users perceive occasional negative impact on their schoolwork. Likewise $6.3 \%$ of moderate users and $14.8 \%$ of heavy users perceive frequent negative impact on school work. Combined $56.3 \%$ of moderate users and $83.6 \%$ of heavy users perceive either occasional or frequent negative impact on schoolwork. 


\section{Issues in Information Systems}

Volume 13, Issue 2, 380-389, 2012

\begin{tabular}{|l|c|c|c|c|}
\hline \multicolumn{5}{|c|}{ Table 1 Social Media Use and Academic Impact } \\
\hline & \multicolumn{2}{|c|}{ Within 2 hours per day } & \multicolumn{2}{c|}{ More than 2 hours per day } \\
\hline $\begin{array}{c}\text { Academic } \\
\text { Impact }\end{array}$ & Frequency & Percentage & Frequency & Percentage \\
\hline Never & 42 & $43.8 \%$ & 25 & $20.5 \%$ \\
\hline Occasionally & 48 & $50.0 \%$ & 79 & $64.8 \%$ \\
\hline Frequently & 6 & $6.3 \%$ & 18 & $14.8 \%$ \\
\hline Total & 96 & $100.0 \%$ & 122 & $100.0 \%$ \\
\hline
\end{tabular}

\begin{tabular}{|l|c|r|rr|}
\hline \multicolumn{5}{|c|}{ Table 2 Chi-Square Tests of Academic Impact of Social Media Use } \\
\hline & Value & df & Asymp. Sig. (2-sided) \\
\hline Pearson Chi-Square & $14.993^{\mathrm{a}}$ & 2 & .001 \\
\hline Likelihood Ratio & 15.176 & 2 & .001 \\
\hline Linear-by-Linear Association & 14.253 & 1 & .000 \\
\hline
\end{tabular}

In order to validate these findings Chi-Square Tests (Table 2) and Cross Tabulation Tests (Table 3) were run. Results of the Chi-Square tests and Cross Tabulation tests verify that the time spent on social media does significantly impact a student's ability to get assignments and other schoolwork completed on time and to the best of their ability. 


\section{Issues in Information Systems}

Volume 13, Issue 2, 380-389, 2012

\begin{tabular}{|c|c|c|c|c|c|}
\hline \multirow[t]{3}{*}{ Table 3} & \multicolumn{5}{|c|}{ Cross Tabulation of Academic Impact of Social Media Use } \\
\hline & & & \multicolumn{2}{|c|}{ SM_Usage_02 } & \multirow[b]{2}{*}{ Total } \\
\hline & & & 1.00 & 2.00 & \\
\hline \multirow[t]{9}{*}{ Academic Impact } & & Count & 42 & 25 & 67 \\
\hline & & Expected Count & 29.5 & 37.5 & 67.0 \\
\hline & & $\%$ within Academic Impact & $62.7 \%$ & $37.3 \%$ & $100.0 \%$ \\
\hline & & Count & 48 & 79 & 127 \\
\hline & & Expected Count & 55.9 & 71.1 & 127.0 \\
\hline & & $\%$ within Academic Impact & $37.8 \%$ & $62.2 \%$ & $100.0 \%$ \\
\hline & 3 & Count & 6 & 18 & 24 \\
\hline & & Expected Count & 10.6 & 13.4 & 24.0 \\
\hline & & $\%$ within Academic Impact & $25.0 \%$ & $75.0 \%$ & $100.0 \%$ \\
\hline \multirow[t]{3}{*}{ Total } & & Count & 96 & 122 & 218 \\
\hline & & Expected Count & 96.0 & 122.0 & 218.0 \\
\hline & & \% within Academic Impact & $44.0 \%$ & $56.0 \%$ & $100.0 \%$ \\
\hline
\end{tabular}

More female than male students believe that social media use negatively impacts their schoolwork. As shown by Table $4,79.3 \%$ of female and $62.6 \%$ of male students believe that their schoolwork suffers as a result of using social media. This parallels the findings that female students use social media more frequently than male.

\begin{tabular}{|c|r|r|r|r|}
\hline \multicolumn{5}{|c|}{ Table 4 Academic Impact and Gender } \\
\hline & \multicolumn{2}{|c|}{ Female } & \multicolumn{2}{c|}{ Male } \\
\hline $\begin{array}{c}\text { Negative } \\
\text { Academic } \\
\text { Impact }\end{array}$ & Frequency & Percentage & Frequency & Percentage \\
\hline Never & 18 & $20.7 \%$ & 49 & $37.4 \%$ \\
\hline Occasionally & 59 & $67.8 \%$ & 68 & $51.9 \%$ \\
\hline Frequently & 10 & $11.5 \%$ & 14 & $10.7 \%$ \\
\hline & 87 & $100.0 \%$ & 131 & $100.0 \%$ \\
\hline
\end{tabular}

Gender is a factor in time spent using social media. As shown by Table 5 female students spend more time per day using social media than do male students. A majority of female students $(67.4 \%)$ spend more than two hours per day whereas only $47.3 \%$ of male students spend more than two hours per day using social media. 


\section{Issues in Information Systems}

Volume 13, Issue 2, 380-389, 2012

\begin{tabular}{|l|c|c|c|c|}
\hline \multicolumn{5}{|c|}{ Table 5 Gender and Social Media Use } \\
\hline & \multicolumn{2}{|c|}{ Female } & \multicolumn{2}{c|}{ Male } \\
\hline $\begin{array}{c}\text { Time Spent } \\
\text { per Day using } \\
\text { Social Media }\end{array}$ & Frequency & Percentage & Frequency & Percentage \\
\hline 0 & 1 & $1.1 \%$ & 8 & $6.2 \%$ \\
\hline $1-2$ hours & 28 & $31.5 \%$ & 60 & $46.5 \%$ \\
\hline 2-3 hours & 31 & $34.8 \%$ & 27 & $20.9 \%$ \\
\hline $3-4$ hours & 15 & $16.9 \%$ & 20 & $15.5 \%$ \\
\hline Over 4 hours & 14 & $15.7 \%$ & 14 & $10.9 \%$ \\
\hline & 89 & $100.0 \%$ & 129 & $100.0 \%$ \\
\hline
\end{tabular}

Gender is not a factor in student perception of the number of people who view their social media postings. As shown by Table 6 over 38\% of students surveyed believe that their postings are seen by 100 or more people. It is interesting to note that there are few major differences between female and male views on this issue.

\begin{tabular}{|l|r|r|r|r|}
\hline \multicolumn{2}{|c|}{ Table 6 Student Perception of the Number of People Viewing } \\
Information Their Social Media Postings \\
\hline & \multicolumn{2}{|c|}{ Female } & \multicolumn{2}{c|}{ Male } \\
\hline $\begin{array}{c}\text { Number of } \\
\text { People } \\
\text { Viewing } \\
\text { Information }\end{array}$ & Frequency & Percentage & Frequency & Percentage \\
\hline $0-20$ & 9 & $10.1 \%$ & 18 & $14.2 \%$ \\
\hline $21-40$ & 17 & $19.1 \%$ & 16 & $12.6 \%$ \\
\hline $41-60$ & 14 & $15.7 \%$ & 24 & $18.9 \%$ \\
\hline $61-80$ & 7 & $7.9 \%$ & 11 & $8.7 \%$ \\
\hline $80-100$ & 8 & $9.0 \%$ & 9 & $7.1 \%$ \\
\hline Over 100 & 34 & $38.2 \%$ & 49 & $38.6 \%$ \\
\hline & 89 & $100.0 \%$ & 127 & $100.0 \%$ \\
\hline
\end{tabular}




\section{Issues in Information Systems}

Volume 13, Issue 2, 380-389, 2012

Students are largely satisfied with the Security and Privacy Policies of Social Media Sites. As shown by Table 7 an average of approximately $76 \%$ of students are somewhat satisfied or satisfied with security warnings contained in social media sites, $82 \%$ with sites' guidelines for how to use the site safely, $72 \%$ with breach of security notification policies, $84 \%$ with the ability to control who sees the information you have posted, and $78 \%$ with the site's ability to protect your information. Although females are more confident in a site's notification of security breach policies, there are few other gender differences in these perceptions.

\begin{tabular}{|c|c|c|c|c|c|}
\hline \multirow[b]{2}{*}{$\begin{array}{c}\text { Security and } \\
\text { Privacy } \\
\text { Policies }\end{array}$} & \multirow[b]{2}{*}{ Satisfaction } & \multicolumn{2}{|c|}{ Female } & \multicolumn{2}{|c|}{ Male } \\
\hline & & Frequency & Percentage & Frequency & Percentage \\
\hline \multirow{3}{*}{$\begin{array}{l}\text { Warning about } \\
\text { the security of } \\
\text { your } \\
\text { information }\end{array}$} & Never & 18 & $20.7 \%$ & 35 & $27.1 \%$ \\
\hline & Somewhat Satisfied & 47 & $54.0 \%$ & 66 & $51.2 \%$ \\
\hline & Satisfied & 22 & $25.3 \%$ & 28 & $21.7 \%$ \\
\hline \multirow{3}{*}{$\begin{array}{l}\text { Guideline } \\
\text { about how to } \\
\text { use the site } \\
\text { safely }\end{array}$} & Never & 12 & $13.6 \%$ & 28 & $21.5 \%$ \\
\hline & Somewhat Satisfied & 51 & $58.0 \%$ & 61 & $46.9 \%$ \\
\hline & $\overline{\text { Satisfied }}$ & 25 & $28.4 \%$ & 41 & $31.5 \%$ \\
\hline \multirow{3}{*}{$\begin{array}{l}\text { Notification of } \\
\text { security } \\
\text { breaches of } \\
\text { your } \\
\text { information }\end{array}$} & Never & 20 & $22.7 \%$ & 43 & $33.1 \%$ \\
\hline & Somewhat Satisfied & 52 & $59.1 \%$ & 59 & $45.4 \%$ \\
\hline & Satisfied & 16 & $18.2 \%$ & 28 & $21.5 \%$ \\
\hline \multirow{3}{*}{$\begin{array}{l}\text { Your ability to } \\
\text { control who } \\
\text { sees your } \\
\text { information }\end{array}$} & Never & 14 & $15.9 \%$ & 20 & $15.5 \%$ \\
\hline & Somewhat Satisfied & 39 & $44.3 \%$ & 51 & $39.5 \%$ \\
\hline & Satisfied & 35 & $39.8 \%$ & 58 & $45.0 \%$ \\
\hline \multirow{3}{*}{$\begin{array}{l}\text { The site's } \\
\text { ability to } \\
\text { protect your } \\
\text { information }\end{array}$} & Never & 19 & $21.6 \%$ & 29 & $22.5 \%$ \\
\hline & Somewhat Satisfied & 50 & $56.8 \%$ & 66 & $51.2 \%$ \\
\hline & Satisfied & 19 & $21.6 \%$ & 34 & $26.4 \%$ \\
\hline
\end{tabular}

Students indicate substantial confidence in how their postings will be used. As shown by Table 8, a whopping $91.2 \%$ of students believe that their postings will be used as they intend, $86.2 \%$ believe that they will also be used by 


\section{Issues in Information Systems}

Volume 13, Issue 2, 380-389, 2012

marketers to market directly to them, $77.6 \%$ believe that their postings will be used by businesses for employment decisions, and $71.9 \%$ believe that they will be used by others for malicious purposes. Such high confidence would seem to argue that students are aware of serious risk of misuse, but believe the benefits of social media outweigh the risks. As with perceptions of security and privacy policies, there are few differences between female and male students in their views of how their postings will be used.

\begin{tabular}{|c|c|c|c|c|c|}
\hline \multicolumn{6}{|c|}{ Table 8 Perception on Social Media Use \& Gender } \\
\hline & & \multicolumn{2}{|c|}{ Female } & \multicolumn{2}{|c|}{ Male } \\
\hline $\begin{array}{l}\text { Use of Social } \\
\text { Media Postings } \\
\text { by Others }\end{array}$ & Satisfaction & Frequency & Percentage & Frequency & Percentage \\
\hline \multirow{3}{*}{$\begin{array}{l}\text { Exclusively as } \\
\text { you intended }\end{array}$} & Never & 6 & $6.8 \%$ & 14 & $10.9 \%$ \\
\hline & Somewhat Satisfied & 55 & $62.5 \%$ & 79 & $61.2 \%$ \\
\hline & Satisfied & 27 & $30.7 \%$ & 36 & $27.9 \%$ \\
\hline \multirow{3}{*}{$\begin{array}{l}\text { By businesses } \\
\text { to market to } \\
\text { you }\end{array}$} & Never & 12 & $13.6 \%$ & 18 & $14.0 \%$ \\
\hline & Somewhat Satisfied & 48 & $54.5 \%$ & 77 & $59.7 \%$ \\
\hline & Satisfied & 28 & $31.8 \%$ & 34 & $26.4 \%$ \\
\hline \multirow{3}{*}{$\begin{array}{l}\text { By businesses } \\
\text { for } \\
\text { employment } \\
\text { decisions }\end{array}$} & Never & 20 & $23.0 \%$ & 28 & $21.9 \%$ \\
\hline & Somewhat Satisfied & 55 & $63.2 \%$ & 74 & $57.8 \%$ \\
\hline & Satisfied & 12 & $13.8 \%$ & 26 & $20.3 \%$ \\
\hline \multirow{3}{*}{$\begin{array}{l}\text { By others for } \\
\text { malicious } \\
\text { purposes }\end{array}$} & Never & 20 & $23.3 \%$ & 42 & $33.1 \%$ \\
\hline & Somewhat Satisfied & 58 & $67.4 \%$ & 74 & $58.3 \%$ \\
\hline & Satisfied & 8 & $9.3 \%$ & 11 & $8.7 \%$ \\
\hline
\end{tabular}

Students believe that the benefits of social media out-weigh the risks of its use. As shown by Table 9, an average of $54.3 \%$ of students agree that the benefits of social media outweigh its risks, and an average of $45.4 \%$ are neutral as to whether benefits outweigh the risks. Only $2.9 \%$ of responding students disagree that benefits outweigh the risks. 


\section{Issues in Information Systems}

Volume 13, Issue 2, 380-389, 2012

\begin{tabular}{|l|c|c|c|c|}
\hline \multicolumn{2}{|c|}{ Table 9 Trade-off Between the Risks and Benefits of Social Media Use by Gender } \\
\hline & \multicolumn{2}{|c|}{ Female } & \multicolumn{2}{c|}{ Male } \\
\hline $\begin{array}{c}\text { The benefits of social } \\
\text { media out-weigh the risks } \\
\text { of social media }\end{array}$ & Frequency & Percentage & Frequency & Percentage \\
\hline I agree & 49 & $55.1 \%$ & 70 & $53.4 \%$ \\
\hline Neutral & 39 & $43.8 \%$ & 55 & $42.0 \%$ \\
\hline I Disagree & 1 & $1.1 \%$ & 6 & $4.6 \%$ \\
\hline & 89 & $100.0 \%$ & 131 & $100.0 \%$ \\
\hline
\end{tabular}

Students overwhelming view communicating and staying in touch with classmates, friends and families as the primary benefit of using social media. The survey concluded with two open text response questions. The first of these was "What are the primary benefits to you of using Social Media?" Most students (207) took the time to type an answer to this question. The words communication, interact, stay in touch, entertainment, share photos and videos, were in most of the responses along with one "It is interesting the see the stupid stuff people do."

Students view invasion of privacy, identity theft, and misuse of information as the primary risks of using social media. The second concluding open text response question was "What are the primary risks to you of using Social Media?" Again most students, this time 197 took the time to type an answer. The words privacy, information leaking, my information used against me, revealing too much information, identity theft, information in the hands of the wrong people, others posting untrue things about me, and a number of comments related to "people seeing things and stalking me" were in the responses.

\section{CONCLUSIONS}

Social media is not likely to be a passing phenomenon. Not only are hundreds of millions of people, many of them young, using social media but they are doing so while cognizant of the risks. There is a deep seated need to communicate and stay in touch with friends, classmates and family. Young student users are comfortable with the technology and they use computers, notepads, and most importantly smart phones to constantly stay in touch. While students do not report being overly satisfied with Social Media security, they report feeling that the benefits of using Social Media outweighs the risks. A large majority believe that their postings will be used as intended, but $2 / 3$ of the respondents also believe that they will used by others for malicious purposes. Once on-line or "on the grid" use increases to the point where $50 \%$ of moderate users and $65 \%$ of heavy users believe that their use of social media at least occasionally negatively impacts their ability to get their assignments and other schoolwork completed on time and to the best of their ability. Based on survey results, our conclusion is that students do not perceive the use of Social Networking as exposing them to excessive risk.

\section{FUTURE RESEARCH}

Findings of this study indicate a certain intensity of conviction on the part of users to forge ahead with using Social Media regardless of risk, and as use increases and intensifies so does the motivation of business to find ways to convert what appears to be a personal use vehicle into a highly profitable economic venture. In many ways social media is supplanting traditional broadcast and print media as a way to reach the masses whether they are willing or not. It would be useful to repeat this survey, ,focusing on the impact of using Social Networking on student academic performance. 


\section{Issues in Information Systems}

Volume 13, Issue 2, 380-389, 2012

\section{REFERENCES}

1. (2012). "7 Signs We're Living in the Post-Privacy Era," January 3, found at:

www.technolog.msnbc.msn.com/_news/2012/01/03/9808600-7-signs-we're-living-in-the-post-privacy-era.

2. __ (2012). _"Harris Poll," found at: http://finance.yahoo.com/blogs/daily-ticker/facebook-gotreputation-problem-harris-poll-143142912.html.

3. (2009). "Forty-Five Percent of Employers Use Social Networking Sites to Research Job

Candidates," August 19, found at:

http://careerbuilder.com/share/aboutus/pressreleasesdetail.aspx?id=pr519\&sd=8\%2009.

4. (2012). "Google's New Privacy Policy: When Consumers' Worlds Collide, the Company Stands to

Profit," February 15, found at: http://Knowledge.wharton.upenn.edu/article.cfm?articleid=2942.

5. (2011). "Facebook's Ethan Beard: Driving Engagement - and Growth - Through Social Design," July 27, found at: http://Knowledge. wharton.upenn.edu/article.cfm?articleid=2819.

$6 . \quad$ (2010). "Act Now, Apologize Later: Will Users 'Friend' Facebook's Latest Intrusion on Privacy?," May 12, found at: http://Knowledge. wharton.upenn.edu/article.cfm?articleid=2482.

$7 . \quad$ (2008). "Scrabulous and the New Social Operating System: How Facebook Gave Birth to an Industry," January 23, found at: http://Knowledge. wharton.upenn.edu/article.cfm?articleid=1883.

8. Angwin, J. (2012). "Google Plans to Track Data Across Services: Privacy Changes Take Effect March 1", January 25, The Wall Street Journal, 19, p. B3. Print.

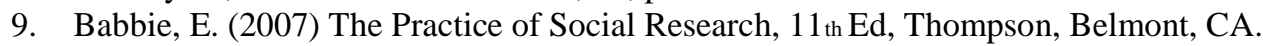

10. Catan, T. (2012). "Con Artist Starred in Sting That Cost Google Millions", January 25, The Wall Street Journal, 19, p. A1. Print.

11. Fowler, G., S. Raice \& A. Efrati. (2012). "Spam Finds New Target --- Facebook and Twitter Build Up Their Defenses as Hackers Attack Social Networks", January 4, The Wall Street Journal (Eastern Edition), p. B.1. Retrieved February 3, 2012, from ABI/INFORM Global. (Document ID: 2552255091).

12. Hardy, M. (2012). "Facebook Risks," found at: http://socialnetworking.lovetoknow.com/Facebook_Risks.

13. Lederer, K. (2012). "Pros and Cons of Social Media in the Classroom", Campus Technology, January 19, found at: http://campustechnology.com/articles/2012/1/19/pros-and-cons-of-social-media-in-the-classroom.

14. Letzing, J. (2011). "Facebook Flaw Exposes Its CEO", December 7, The Wall Street Journal, 134, p. B6. Print.

15. Sengupta(1), S. (2011). "F.T.C. Settles Privacy Issue At Facebook," November 30, [Business/Financial Desk]. New York Times (Late Edition (east Coast)), p. B.1. Retrieved February 3, 2012, from ProQuest Newsstand. (Document ID: 2522757231).

16. Sengupta(2), S. (2011). "Researchers Find A Hole in Skype," December 5, [Business/Financial Desk], New York Times (Late Edition (east Coast)), p. B.5. Retrieved February 3, 2012, from ProQuest Newsstand. (Document ID: 2526419961).

17. Sharma, A. (2012). "Google, Facebook Fight Indian Censorship Demands," January 17, The Wall Street Journal (Online). Retrieved February 3, 2012, from ABI/INFORM Global. (Document ID: 2561825731).

18. Steel, E. (2011). “'Adware' Apps Bug Facebook, Google”, December 9, The Wall Street Journal, 136, p. B1. Print. 